\title{
Imperial Cult Processions and Landscape in the Greek Cities of the Roman Empire: The Case of The Demosthenia of Oenoanda
}

\author{
Elena Muñiz Grijalvo and Fernando Lozano
}

The famous epigraphic dossier on the creation of the Demosthenia by C. Iulius Demosthenes in the city of Oenoanda is for many reasons an extraordinary testimony. ${ }^{1}$ It comprises of several documents: following a letter in which Demosthenes offers an account of how he has defrayed the cost of organising a new pentaeteric festival in $124 \mathrm{CE}$ (to which Hadrian gives his seal of approval in the dossier's first document), there is a third document in which the city of Oenoanda undertakes to organise the emperor cult in the framework of a new imperial festival. ${ }^{2}$ Among the sea of details that the document contains, we will dwell in this paper on the information that it provides on the situation of this specific territory of Lycia during the Imperial Age. ${ }^{3}$

1 This paper has been written with the support of the research projects "Discursos del Imperio Romano: Las procesiones y la construcción de la comunidad imperial" (PGC2018-o9650o$\mathrm{B}_{-} \mathrm{C}_{32}$ ) and "Discursos del Imperio Romano: Palabras y Rituales que Construyeron el Imperio" (PGC2018-o965oo-B-C31), financed by the Spanish Ministerio de Ciencia, Innovación y Universidades.

2 The dossier includes two more documents: "IV. The formal resolution of the council and people of the Termessians at Oenoanda, in the light of Demosthenes' benefactions, to provide a testimonial for him to the provincial governor and to request confirmation of the various tax privileges which had been agreed. v. The subscript of the governor, probably simply attached to the decree rather than to an elaborated petition", see S. Mitchell, 'Festivals, games, and civic life in Roman Asia Minor', Journal of Roman Studies 8o (1990), 187. The complete dossier in M. Wörrle, Stadt und Fest im kaiserzeitlichen Kleinasien (Munich 1988) (with translation; cf. SEG 38.1462). A complete discussion of the text in Wörrle; Mitchell with translation; C.P. Jones, Review of M. Wörrle, Stadt und Fest, JRA 3 (1990), 484-88; F. Gascó, Evergetismo (unpublished); P. Guinea, 'Las Demostenias de Enoanda y los bueyes ciudadanos', in F. Presedo et al. (eds.), Chaire. Homenaje al profesor Fernando Gascó (Sevilla 1997), 463-471.

3 Lycia was a rather mountainous region, with a shortage of arable land and a relatively limited population. It only became a Roman province in $43 \mathrm{CE}$. Although more research has been conducted on its cities, the countryside is also relatively well known: there were "numerous small plains surrounded by mountains, most easily exploited by means of small nucleated settlements", J.R. Patterson, 'Settlement, city and elite in Samnium and Lycia', in J. Rich and A. Wallace-Hadrill (eds.), City and Country in the Ancient World (London 1991), 147-68. For 
Surprisingly, the document describes the active participation of Oenoanda's territory (its villages and monagriai) ${ }^{4}$ in the imperial cult ceremonies held in the city. In this respect, it is an all but unique testimony. These types of inscriptions dealing with the organisation of religious life in the Greek cities of the Empire did not usually contain references to their territories or constituencies. Normally, the population was classified according to other criteria, such as the possession of citizenship (citizens/metoikoi/foreigners) or the affiliation to a tribe. ${ }^{5}$ In the case of Oenoanda, however, the epigraphic document states that on the days set aside for the rituals in honour of the emperor a procession through the city's theatre, including a joint sacrifice by the city and the territory, was supposed to be organised. This procession apparently consisted of the sacrificial animals provided by the chief magistrates and priests, and was followed by the processions furnished by the villages, whose names, sometimes in pairs and sometimes in groups of three, appear in the inscription, too.

This testimony is evidently exceptional and, therefore, should not simply serve to provide a general overview of the relations between the Greek cities and their territories in the Imperial Age. Instead, it begs the question of why the assembly and council of Oenoanda decided to include the villages in

an overview of Lycia in Roman times, see A.H.M. Jones, Cities of the Eastern Roman Empire (Oxford 1937), 96-110; T.R. Bryce, The Lycians in Literary and Epigraphic Sources (Copenhagen, 1985); Patterson 1991, op. cit. (n. 3); R. Haensch, Capita Provinciarum. Statthaltersitze und Provinzialverwaltung in der römischen Kaiserzeit (Mainz 1997), 290-297; M. Harrison, Mountain and Plain: From the Lycian Coast to the Phrygian Plateau in the Late Roman and Early Byzantine Period (Ann Arbor 2001); H. Brandt and F. Kolb, Lycia et Pamphylia: Eine römische Provinz im Südwesten Kleinasiens (Mainz 2005). As for the city of Oenoanda, its first flourishing under the early Empire and its prosper situation in the late second and early third centuries, see Wörrle 1988, op. cit. (n. 2); J.J. Coulton, 'Termessians at Oenoanda', AnSt 32 (1982), 115-121; J.H. Coulton, 'Two buildings of Oinoanda', PCPhS n.s. 29 (1983), 1-20. See also the important bronze stele which contains the treaty between Rome and Lycia of 46 BCE ( $S E G$ 55.1452) and the commentary on the inscription in S. Mitchell, 'The treaty between Rome and Lycia of 46 BC', in R. Pintaudi (ed.), Papyri Graecae Schøyen I (Florence 2005), 163-258. Mitchell suggests that the Lycians had been at war with the people of Oenoanda and the treaty sanctioned a diminishment of the city's territory.

4 For the meaning of monagria, see $S E G$ 38.1462C (p. 448); Wörrle 1988, op. cit. (n. 2), 140. Patterson 1991, op. cit. (n. 2), translates it as 'estate centre', and Mitchell 199o, op. cit. (n. 2), 186, as 'farmstead'.

5 A. Chankowski, 'Processions et cérémonies d'accueil: une image de la cité de la base époque hellénistique?', in P. Fröhlich and C. Müller (eds.), Citoyenneté et participation à la basse époque hellénistique (Geneva 2010), 185-206 and S. Paul, 'Sharing the civic sacrifice: Civic feast, procession, and sacrificial division in the Hellenistic period', in F. van den Eijnde, J. Blok and R. Strootman (eds.), Feasting and Polis Institutions (Leiden and Boston 2018) analyse several Hellenistic examples; see also Guinea 1997, op. cit. (n. 2), 469, n. 19. 
the organisation of the imperial cult in such an extraordinary fashion. ${ }^{6}$ Some scholars, including Michael Wörrle, Fernando Gascó and Stephen Mitchell, have underscored Oenoanda's desire to foster integration by forging stronger links with its villages, the Hellenic community and even the Empire. Gascó defines this as an authentic "act of political engineering". ${ }^{7}$ Others have preferred to put the emphasis on the initiative's possible tributary character, whose ultimate purpose would have been to burden the villages with a new tax, and on the subordination of the territory that was implicit in that ritual representation of the city. ${ }^{8}$

The aim here is to put forward a third explanation for the noteworthy appearance of the villages in the dossier of Oenoanda which relates to the involvement of the city's territory in the dynamics of imperial cult festivals. It should be noted that the document in question deals precisely with the organisation of the imperial cult festivals: once the creation of the new games had been approved, the city's intention was that "the festival should be adorned in every way" and that "devotion towards the emperor who has supported it should be completely fulfilled" (III. $5^{6-57)} \cdot .^{9}$ Thereinafter, the text consists in a description of the ceremonies and their participants and principal actors (ll. $5^{8-87}$ ). This is therefore the context in which the villages appear. Let us take a look at the description of the procession:

6 As a point of fact, this was the issue that would give rise to greater controversy in the years following the publication of the inscription as well as in the comprehensive study by Wörrle 1988, op. cit. (n. 2 ).

7 Wörrle 1988, op. cit. (n. 2); M. Wörrle, 'La festa' in S. Settis (ed.), I Greci. Storia, cultura, arte, società II.3 (Turin 1998); F. Gascó, Evergetismo (unpublished: Gascó's untimely death in 1995 prevented the completion of this seminal work. We would like to thank E. Falque's generosity in allowing us to consult Gascó's project). Special mention must be made of Mitchell's idea about the integration of the villages, that in his opinion might have been due to the gratitude of the villages and the magistrates of Oenoanda for the generosity of Demosthenes, cf. S. Mitchell, Anatolia. Land, Men and Gods in Asia Minor I (Oxford and New York 1993), 210, n. 73 .

8 Guinea 1997, op. cit. (n. 2). From the little that is known about the city-territory articulation in Roman times, it can be deduced above all that the variety of situations is almost infinite; but the subordinate character of the villages, which almost always appear as tributaries, is usually emphasised: cf. D.Chr. 40.10; M. Sartre, L'Orient romain (Paris 1991); M. Corbier, 'City, territory and taxation', in Rich and Wallace-Hadrill 1991, op. cit. (n. 3), 211-240; Patterson 1991, op. cit. (n. 3), 169 extends on the impact of the Roman empire on Lycia, stressing how the size of rural properties continued to grow in order to cope with "the increased level of competition within the towns".

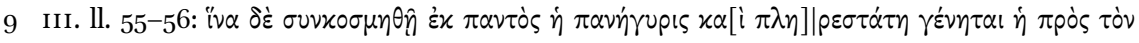

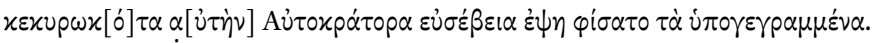


(ll. 61-63) ten sebastophoroi should also be chosen by him who, wearing white clothing and a crown of celery leaves, will handle and bring forward and escort the images of the emperors and the image of our ancestral god Apollo, and the previously mentioned holy altar. ${ }^{10}(11.68-74)$ The following will process through the theatre and will sacrifice together during the days of the festival: The agonothete himself, one bull; the civic priest of the emperors and the priestess of the emperors, one bull; the priest of Zeus, one bull; the three panegyriarchs, one bull; the secretary of the council and (70) the five prytaneis, two bulls; the two market supervisors of the city, one bull; the two gymnasiarchs, one bull; the four treasurers (tamiai), one bull; the two paraphylakes [rural police-officers], one bull; the ephebarch, one bull; the paidonomos, one bull; the supervisor of the public buildings, one bull; of the villages, Therseno with Armadu, Arissos, Merlakanda, Mega Oros, [---]lai, Kirbu, Euporoi, Oroata, [...] ake, Valo, and Yskapha, with their associated farmsteads (monagriai), two bulls (this is followed by a list of at least 25 villages, some with associated monagriai [farmsteads]). ${ }^{11}$

In an attempt to explain why Oenoanda decided to organise a procession with the explicit and prominent participation of the villages, we will focus on the organisation and significance of the processions. This perspective has not been fully explored before, even though the procession was probably one of the most eye-catching parts of the festival, and one of the most unequivocal ways to (re)present civic identity. In some respects, imperial cult processions were a ritual novelty where tradition and innovation converged and offered new semiotic and performative possibilities. We will therefore employ a dual approach: firstly, we will take into account the ritual logic of processions, that is, that only the people participating in them had a share in their benefits. In this

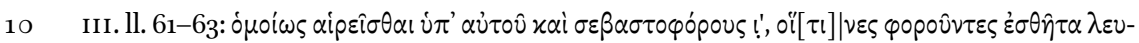

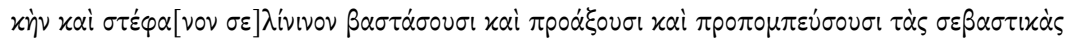

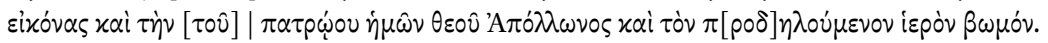

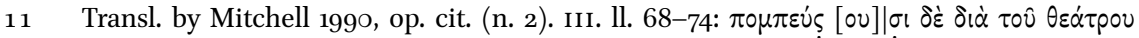

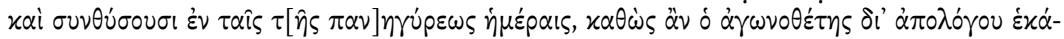

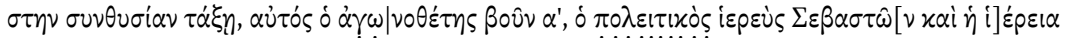

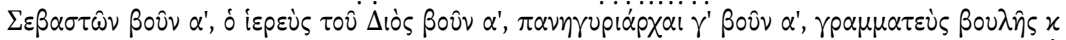

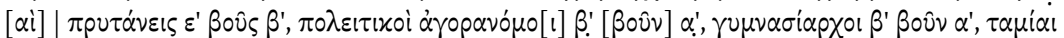

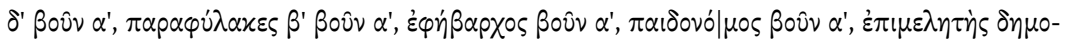

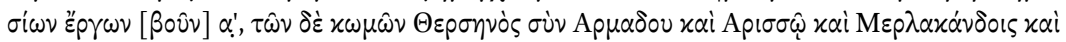

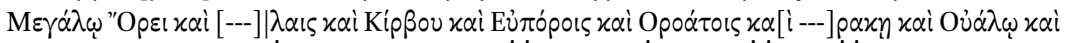

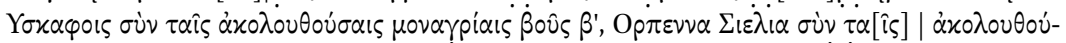

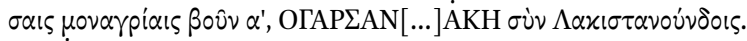


case, we will see how the imperial cult procession at Oenoanda offered a new framework of participation in civic life. Secondly, imperial cult also brought with it new opportunities for social and political promotion. In this light, we will examine the interest that Demosthenes and the city of Oenoanda might have had in offering an impressive spectacle, to which end it was desirable to involve the territory as a whole. It was precisely the new ritual involvement of the territory what fostered a stronger perception of unity between town and country, and probably of the importance of the town and its monumental buildings. The impact of the Roman empire on landscape was not necessarily due to an actual physical reshaping of the territory, but rather due to landscape as a social product, as an ideologically burdened image which weighed heavily on reality. ${ }^{12}$

1. The processions that were organised in honour of the emperors were, in some respects, a significant ritual novelty. Traditionally, the major processions in which the civic institutions intervened involved escorting (ротреио) the sacrificial animals destined to be offered to the gods to the place of sacrifice. ${ }^{13}$ There are several excellent examples, especially from the Hellenistic Age,

12 A useful survey of the multiplicity of interpretations of landscape in P. Howard et al. (eds.), The Routledge Companion to Landscape Studies (New York 2019, 2nd ed.).

13 The most complete overview of Greek and Roman processions continues to be F. Bömer, s.v. 'pompa', $R E 42$ (1952), 1878-1994; a more general overview may be found in the first volume of the Thesaurus Cultus et Rituum Antiquorum (Basel and Los Angeles 2005). Literature on Graeco-Roman processions usually focuses on particular aspects or different types: for instance, the pompa triumphalis, among the huge amount of bibliography on triumphus, for the pompa itself see T. Itgenshorst, Tota illa pompa. Der Triumph in der römischen Republik (Göttingen 2005); I. Östenberg, Staging the World: Spoils, Captives, and Representations in the Roman Triumphal Procession (Oxford and New York 2009), or the pompa circensis (which has benefited from some recent important work, see P. Arena, Feste e rituali a Roma. Il principe incontra il popolo nel Circo Massimo [Bari 2010]; J. Latham, Performance, Memory, and Processions in Ancient Rome: The pompa circensis from the Late Republic to Late Antiquity [New York and Cambridge 2016]). For more general reflections on processions, see F. Graf, 'Pompai in Greece', in R. Hägg (ed.), The Role of Religion in the Early Greek Polis. Proceedings of the Third International Seminar of Ancient Greek Cult, organized by the Swedish Institute of Athens, 16-18 October 1992 (Stockholm 1996), 55-65; A. Chaniotis, 'Processions in Hellenistic cities: Contemporary discources and ritual dynamics', in R. Alston, O.M. van Nijf and C.G. Williamson (eds.), Cults, Creeds and Contests (Louvain 2013), 21-47; S. Estienne, 'Aurea pompa venit. Présences divines dans les processions romaines', in S. Estienne et al. (eds.), Figures de dieux. Construire le divin en images (Rennes 2014), 337-349; D. Viviers, 'Quand le divin se meut. Mobilité des statues et construction du divin', in Estienne et al. 2014, op. cit., 27-38; I. Östenberg, S. Malmberg and J. Bjørnebye (eds.), The Moving City: Processions, Passages and Promenades in Ancient Rome (London and New York 2015). 
which leave no room for doubt that only those people participating in the procession were eligible to receive all of the benefits, that is to say not only the meat for the subsequent sacrificial banquet, but also their symbolic inclusion in the civic body and ranking in the real or idealised civic hierarchy. ${ }^{14}$ For this reason, the participants were normally divided into citizens and non-citizens (who, in principle, were excluded from civic rites) ${ }^{15}$ and organised in groups according to their civic status: council members, magistrates, priests, youths, neoi and paides. ${ }^{16}$ It was also customary to specify that the city would bear the cost of the most important sacrificial animals, a significant note which gave the sacrifice its public character. Public funds were used to purchase the animals that would subsequently be consumed by the procession's main actors. But participating in the procession was so important that, on occasion, people were encouraged to do so voluntarily, paying for sacrifices out of their own pockets. ${ }^{17}$ And exceptionally, for reasons that will be discussed below, the city was even willing to sponsor the participation of the metoikoi in the procession and the sacrifice, ${ }^{18}$ making it quite clear, nonetheless, that they were noncitizens and would only consume those sacrificial animals reserved for them and would do so on their own. Therefore, these processions were opportunities for the sympompeountes, "those who united in procession", to express their belonging to the city and symbolise their social position. ${ }^{19}$

14 As stated by Östenberg 2009, op. cit. (n. 13), 36: "the ideal pattern of social life".

15 Cf. S. Krauter, Bürgerrecht und Kultteilnahme (Berlin and New York 2004).

16 Some instances: IMagnesia $98=$ LSAM 32; SEG 12.511 = LSAM 81 (Antiocheia ad Pyramum).

17 IG XII 9.89 (Eretria); IMagnesia $100=L S A M 33 \mathrm{~A}-\mathrm{B}$ (Magnesia on the Meander).

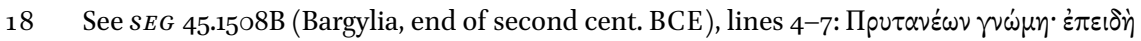

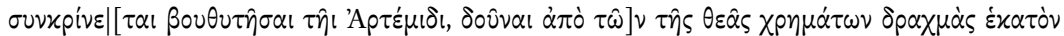

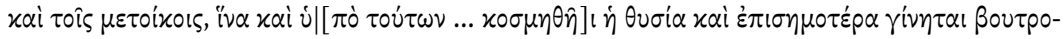

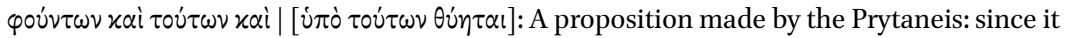
had been decided that for the sacrifice to Artemis it was necessary to add 100 drachmas to the monies of the goddess for the metics, in order that the sacrifice [should be performed by them] and because it would be more magnificent if the metics also offered sacrificial animals.

19 For example in IMagnesia $98=$ LSAM 32 (Magnesia, early second cent. BCE), Lines 46-59:

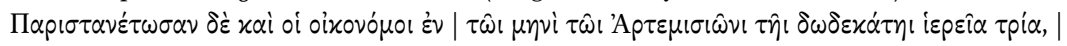

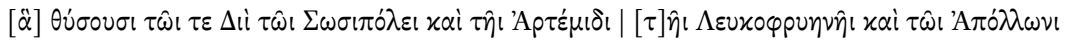

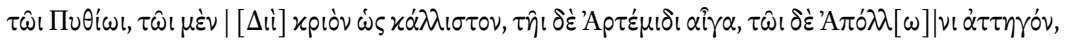

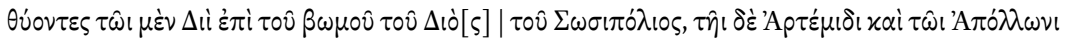

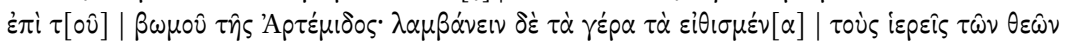

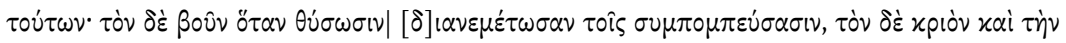

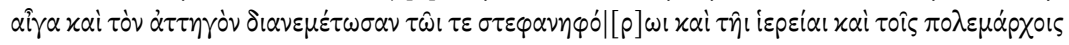

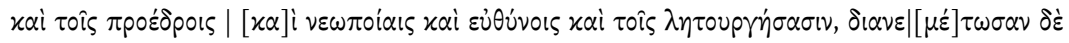
$\tau \alpha \hat{\tau} \tau \alpha$ oi oixovópol. The oikonomoi shall provide on the 12th of Artemision three animals, which they will sacrifice to Zeus Sosipolis, Artemis Leukophryene, and Apollo Pythios; to 
At first glance, the processions linked to the imperial cult were organised following the same principles: only those participating could enjoy their benefits, which is why it was still important to specify who had done so and who had paid for the sacrificial offerings. But, apparently, the chief objective of these new civic processions was not only to evince the civic pecking order, but also to consolidate the new imperial political order. Imperial processions involved the community as a whole to glorify the everlasting reign of the emperors and to state clearly the allegiance of the city to this power which encompassed the whole of the Mediterranean.

Let us now examine the matter in detail. The imperial cult processions that are known followed a very similar pattern. ${ }^{20}$ As with the major processions in honour of the Hellenistic kings and the great figures of the Republican period, this new kind of processions displayed the image of the emperor among the gods. The intention now was not only to escort the sacrificial offerings, but also the emperors to the place where the public at large awaited them. ${ }^{21}$ These processions departed from a sanctuary before passing through the streets to a public space with a recreational function (such as a theatre or amphitheatre),

Zeus the most beautiful ram, to Artemis a goat, and to Apollo a billy goat, and they shall perform the sacrifice to Zeus on the altar of Zeus Sosipolis, to Artemis and to Apollo on the altar of Artemis. The priests of these gods shall receive the honorary portions as usual. They shall divide the ox, once they have sacrificed it, among those who participated in the procession, and they shall divide the ram, the goat, and the billy goat among the stephanephoros, the priestess, the polemarchoi, the proedroi, the neopoioi, the public examiners and those who served in liturgies; the oikonomoi shall be in charge of the división. (transl. by S. Paul).

20 See for example the cases of Gythium, Naples, Messene, Sparta, Ephesos or Akrephias. For Gythium see F. Lozano, La religión del poder. El culto imperial en Atenas en época de Augusto y los emperadores Julio-Claudios (Oxford 2002), 66-72; M.E. Gorrini and E. Calandra, 'Cult practice of a pompé in the Imperial Age: S.E.G. XI.923', Sparta 4 (2008), 3-22. For Gythium, Naples and Messene, see A. Lo Monaco, Il crepuscolo degli dei d'Achaia (Rome 2009). For Ephesos see G. Rogers, The sacred identity of Ephesos (London and New York 1991). See also D. Fishwick, The Imperial Cult in the Latin West II 1 (Leiden 1991), 532-566; B. Edelmann, 'Pompa und Bild im Kaiserkult des römischen Ostens' in J. Rüpke (ed.), Festrituale in der römischen Kaiserzeit (Tübingen 2008), 153-167. For Imperial festivals in Achaia in general, see F. Camia, 'Between tradition and innovation: Cults for Roman emperors in the province of Achaia', in A. Kolb and M. Vitale (eds.), Kaiserkult in den Provinzen des Römischen Reiches. Organisation, Kommunikation und Repräsentation (Berlin and Boston 2016), 255-283 (esp. 259-265); F. Lozano, 'The imperial cult in Achaia', in F. Camia (ed.), Emperor Worship in the Greek-speaking provinces of the Empire (forthcoming).

21 As was customary in the traditional pompae circenses, see Arena 2010, op. cit. (n. 13), N.T. Elkins, 'The procession and placement of imperial cult images in the colosseum', $B S R$ 82 (2014), 73-107; Latham 2016, op. cit. (n. 12). 
where the rest of the rites envisaged in honour of the imperial house were performed. ${ }^{22}$ The aim was to make the most of the huge audience capacity of theatres, amphitheatres, stadiums or circuses in order to cause the greatest impression possible on the audience. Imperial processions and festivals provided the ideal stage for flaunting not only the emperor's power, but also that of the cities that hosted them and that of the euergetai who helped to fund them. ${ }^{23}$ The citizens gathered in those public spaces as members of the audience had ceased, to a great extent, to be active participants in the rites and had become instead mere spectators. ${ }^{24}$ The inscriptions make almost no reference to the citizens' participation in the different civic bodies, which are mentioned far less frequently anyways for they had yielded much of their ritual space to the great public figures.

This general trend is perfectly illustrated in the case of Oenoanda, where the procession, which only passed through the theatre, was formed solely by magistrates and priests. No other civic body had a place in it, except for the villages whose inhabitants probably were not citizens at all or at least not full ones. The participation of the villages was therefore probably due to the desire that they should also share the benefits of the procession. Thus, of the at least 27

22 P. Gros, 'Théâtre et culte impérial en Gaule Narbonnaise et dans la Péninsule Ibérique', in Trillmich and P. Zanker (eds.), Stadtbild und Ideologie. Die Monumentalisierung hispanischer Städte zwischen Republik und Kaiserzeit. Kolloquium in Madrid vom 19. bis 23. Oktober 1987 (Munich 1990), 381-39o; P. Gros, 'Les theatres des provinces occidentales. Le problème des modeles architecturaux et ideologiques', in C. Márquez and A. Ventura (eds.), Jornadas sobre teatros romanos en Hispania (Córdoba 2006), 15-27; E. Rosso, 'Le message religieux des statues divines et imperials dans les théâtres romains: approche contextuelle et typologique', in J.-C. Moretti (ed.), Fronts de scene et lieux de culte dans le theatre antique (Lyon 2009), 89-126.

23 On royal processions in Hellenistic times, see E.E. Rice, The Grand Procession of Ptolemy Philadelphus (Oxford 1983); Chaniotis 2011, op. cit. (n. 13). On social promotion and imperial cult, see F. Lozano, 'La promoción social a través del culto a los emperadores: el caso de Tiberio Claudio Novio en Atenas', Habis 38 (2007), 185-203; F. Camia, 'Imperial priests in second century Greece: A socio-political analysis', in A.D. Rizakis and F. Camia (eds.), Pathways to Power: Civic Elites in the Eastern Part of the Roman Empire (Athens 2008), 23-41; F. Camia, Theoi Sebastoi. Il culto degli imperatori romani in Grecia (Provincia Achaia) nel secondo secolo D.C. (Athens 2011), 181-188; F. Camia, 'Political Elite and Priestly Posts in Athens During the Roman Imperial Period: Some Considerations', Zeitschrift für Papyrologie und Epigraphik 188 (2014), 139-148.

24 Remarkable exceptions to this general picture are, for example, the case of Gythium where magistrates were meant to foster the sacrifices by groups of citizens in the Agora $(S E G 11.923$, l. 30 ), and the altar of Narbona in which provisions were made for its private use: si quis tergere ornare reficere volet, quod benificii causa fiat, ius fasque esto; sive quis hostia sacrum faxit, qui magmentum nec protollat, idcirco tamen probe factum esto; si quis huic arae donum dare augereque volet, liceto (CIL XII 4333B, ll. 11-18). 
bulls offered in sacrifice, 14 were escorted by the representatives of the villages. But rather than being purchased with city funds, the cost of the latter had to be defrayed by the villages themselves or, in all likelihood, by the demarchoi and archidecanoi who were appointed for the occasion..$^{25}$ As was the case in Bargylia, ${ }^{26}$ it seems reasonable to contend that the bulls of the 'non-citizens' were consumed exclusively by 'non-citizens', namely, by the villagers who did not mix with the rest of the city's inhabitants at the banquet.

Hence it seems improbable that the city materially benefited from the villages' contribution to the sacrifice, which also allows us to doubt the merely tributary nature of their involvement in the procession. If the villages did indeed have a notable presence, there must be another explanation. The intention might have been to allow those participating in the procession to have unrestricted access to its main purpose, at which we can glimpse in the lengthy inscriptions from Oenoanda: a 22 day-long festival, including one day exclusively given over to the market and which presumably gave rise to an uninterrupted exchange of merchandise and services during three long weeks. Judging by the decree of the assembly and the council, only those people participating in the procession would have been authorised to trade in the market free of taxes. This was not only the case for the villages, but also doubtlessly for the neighbouring cities that were invited to form part of the procession as a precursor before being allowed to trade in the market with such advantaged conditions.

The importance of the market appears to be paramount in the case of Oenoanda. For in the dossier's second document (the letter in which Demosthenes offers a detailed account of the creation of the new games in the city), it is Demosthenes himself who stresses as his main merit that he is the guarantor of "fair prices in the market" (l. 9) and has built "a food market with three stoas facing it" (ll. 10-11). The third document, whose chief aim was the organisation of the imperial cult in the context of the new games, also lays emphasis on the holding of the market: the chief magistrate of the games was the agonothetes, who was supposed to choose three panegyriarchontes among the members of the council, whose main task was to take charge "of the market and the supply of provisions at the festival, with the power to write up the prices for the purchase of provisions and to inspect and organise the things which are offered for sale, and to punish those who disobey" (ll. 59-62). A little further on, just after referring to the obligatory participation of the villages in the procession and in the joint sacrifice (under the penalty of a fine for those

25 For the meaning of demarchoi and archidecanoi, see Wörrle 1988, op. cit. (n. 2), 145-150.

26 For the case of Bargylia, see below (p. 261). 
who failed to comply) and the bureaucracy that should be set in motion to ensure the correct participation of other cities in both events, there is a significant passage that reads as follows: "There should be no taxes imposed on any of the purchases sold, sacrificed, imported, introduced or exported during all the days of the festival" (11. 88-89). The inscription ends with the order to erect a stela, displaying all of these measures, which should be placed before the statue of Demosthenes which, needless to say, was located "in the stoa in front of the food market" (1. 96).

As a coda, the document stipulates that the city should contact the provincial governor to request him to authorise the tax exemption during the festival (1. 99). The fourth document in the dossier is actually the request sent by the city to the governor in this regard: "tax-free status for items which are imported, introduced, sold, exported, and put up for sale during the days of the festival" (1l. 109-110). In the context of the new games and the imperial cult, the city of Oenoanda was presented with a fresh opportunity to become the mercantile capital of the territory and its surroundings, at least during those weeks. That also appears to have been the priority for Demosthenes, who had dedicated his euergetic energies to consolidating the city's trading potential and who now, by establishing these new games, was taking things to the next level. Accordingly, the ritual logic explains the necessary participation of the main actors of this major festive and economic event in the procession. The villages and neighbouring cities must have occupied a prominent place in the rites because they would then play a leading role in what was to follow.

2. In addition to the foregoing, the development of the imperial cult had other interesting consequences for the territory. In his seminal work on Asia Minor, Price has demonstrated that the imperial cult was mainly urban and that it was embedded in traditional civic religion. ${ }^{27}$ The cult's propagandistic and representative objectives meant that it made itself felt mainly in the Empire's cities where the rituals consecrated to the Caesars obviously had a greater impact and echo. Therefore, according to Price, "the life of the countryside, and especially rural cults, formed a different world from that of the communally organized, Greek urban settlements [...] There was another world of local culture, especially in the countryside, to which the imperial cult remained alien." Following this line of reasoning, Alcock has noted on his study on Roman Greece that the places dedicated to the imperial cult were built mainly in the centre of the poleis. ${ }^{28}$ Recent analyses performed on the

S.R.F. Price, Rituals and power. The Roman Imperial Cult in Asia Minor (Cambridge 1984), 78-100, here 79 .

28 S.E. Alcock, Graecia Capta. The Landscapes of Roman Greece (Cambridge 1993), 180-189. 
type of places consecrated to emperor worship, such as those by Evangelidis, confirm the cult's centrality as well as its principally urban nature. ${ }^{29}$

Be that as it may, the truth is that the establishment of the imperial cult and festive events, like the new festival at Oenoanda, together with the processions that necessarily had to end in the city's principal recreational spaces, must have also altered the relations between the town and its territory for several reasons. Oenoanda would thus have become the focus of attention, at least during a number of days during which ritual activities and, as has been observed, economic life revolved around its centre. The imperial cult festivals were ideal occasions for self-promotion for the Greek cities and their elites who vied with each other to put on the most magnificent show. This is a very well-known issue that has given rise to interesting studies of the feverish building and agonistic activity in which these cities indulged. ${ }^{30}$ Classical authors also broached this matter in their writings: for Dio Chrysostom, "all these things make it natural for the pride of the cities to be enhanced and the dignity of the community to be increased and for it to receive fuller honour both from the strangers within their gates and from the proconsuls as well" $(40,10)$. So, the festival had to have the largest number of participants possible in order to attract the public in droves, as Menander suggests when referring to the topic as a way of paying tribute to a city $(365,30-366,13)$.

The desire that the new civic festival should have the greatest possible impact might have been one of the reasons why the city of Oenoanda decided

29 V. Evangelidis, 'The architecture of the imperial cult in the agoras of the Greek cities', Egnatia 12 (2008), 125-144; V. Evangelidis, 'Agoras and fora: Developments in the central public spaces of the cities of Greece during the Roman period', ABSA 109 (2010), 335-356. It seems, however, that it is becoming increasingly clear that many of the major rural sanctuaries continued to attract the attention of euergetes and emperors alike. Here, we are referring to rural sanctuaries that were, in any case, clearly connected with civic religion, so they do not contradict Price's main argument as stated in 1984, op. cit. (n. 27), 91-100. See for instance: Lozano (forthcoming), op. cit. (n. 20), 51-53; 79 (Rhamnous); T. Mavrojannis, 'Apollo Delio, Atene e Augusto', Ostraka 4 (1995), 85-102 (Delos); K. Clinton, 'Eleusis and the Romans: Late Republic to Marcus Aurelius', in M.C. Hoff and S.I. Rotroff (eds.), The Romanization of Athens (Oxford 1997), 161-181 and F. Camia 'Cultic and social dynamics in the Eleusinian sanctuary under the empire', in E. Muñiz, J.M. Cortés and F. Lozano (eds.), Empire and Religion. Religious Change in Greek Cities under Roman Rule (Leiden and Boston 2017), 45-66 (Eleusis).

30 On this activity and the conflict that it created between Greek cities, see: F. Gascó, Ciudades griegas en conflicto (Madrid 1990); B. Burrell, 'Neokoroi'. Greek Cities and Roman Emperors (Leiden and Boston 2004), 351-354, and A. Heller, 'Les bêtises des Grecs'. Conflicts et rivalités entre cités d'Asie et de Bithynie à l'époque romaine (129 a.C.-235 p.C.) (Bordeaux 2006); F. Lozano, 'Emperor worship and Greek leagues: The organization of supra-civic imperial cult in the Roman east', in Muñiz, Cortés and Lozano 2017, op. cit. (n. 29), 163-169. 
to include the villages in its celebration. After all, as Wörrle recalls, it was not a very important city. In addition, the festival of the Demosthenia was probably a rather mediocre affair, but nonetheless an opportunity to improve the city's position in the Lycian League in particular and in the Empire in general. ${ }^{31} \mathrm{To}$ that end, a festival typical of the Imperial Age was organised: a procession, a sacrifice, a public banquet, the distribution of cash, agones, concerts, plays and, of course, a market. To guarantee its success, the aforementioned activities had to attract the largest crowds possible and the involvement of the villages and the neighbouring cities perhaps had something to do with this. Such was the desire to organise a multitudinous and glittering event that the organisers went so far as to include perioikoi and foreigners in the public rituals.

Yet the participation of non-citizens in a festival paid for by the public purse was no trivial matter. Several studies have concluded that perioikoi and foreigners were excluded, by definition, from the distribution of meat and the banquet following the procession and sacrifice..$^{32}$ Things changed when it was a privately funded celebration, in which case it was customary to extend the invitation to all those present in the city at a given time. There are, indeed, documented cases in which foreigners were invited to participate, provided that they paid for their own sacrificial victims. ${ }^{33}$ In contrast, public funds were used to purchase animals that were intended solely for the consumption of citizens.

31 Wörrle 1998, op. cit. (n. 7), 1171. On the Koinon of Lycia see J. Deininger, Die Provinziallandtage der römischen Kaiserzeit (Munich and Berlin 1965), 73-81; S. Jameson, 'The Lycian league: Some problems in its administration', in W. Haase and H. Temporini (eds.), ANRW 2.7.2 (Berlin 1980), 832-855; Burrell 2004, op. cit. (n. 30), 253-256; E. Guerber, Les cités grecques dans l'Empire romain. Les privilèges et les titres des cités de l'Orient hellénophone d'Octave Auguste à Dioclétien (Rennes 2009), 100-101; D. Reitzenstein, Die lykischen Bundespriester. Repräsentation der kaiserzeitlichen Elite in Lykien (Berlin 2011) (high priest) and D. Reitzenstein, 'Agonistik und Kaiserkult in Lykien', in Kolb and Vitale 2016, op. cit. (n. 20), 133-155; D. Campanille, 'Specificità delle origini e dello sviluppo del culto imperiale in Licia', in Kolb and Vitale 2016, op. cit. (n. 20), 79-95.

32 P. Schmitt Pantel, La cité au banquet (Paris 1992), 383-384; N. Deshours, L'été indien de la religion civique. Étude sur les cultes civiques dans le monde égéen à l'époque hellénistique tardive (Bordeaux 2011), 272-274.

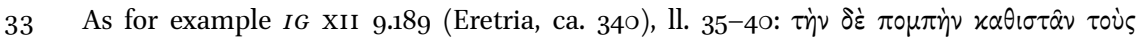

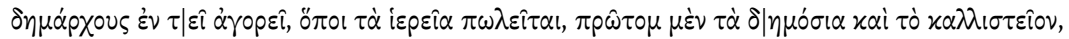

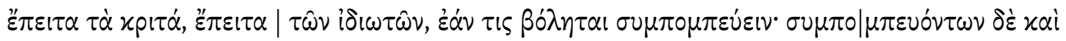

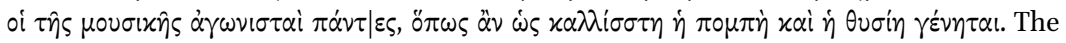
demarchs shall organize the procession in the agora, where the sacrificial animals are sold; first (come) the animals financed by public funds and the beauty prize, then the chosen animals, and afterwards, the animals provided by individuals, if they wish to join in the procession $(\sigma \nu \mu \pi \circ \mu \pi \varepsilon v \varepsilon v)$. All the contestants in music contests shall join in the procession, so that the procession and the sacrifice will be as beautiful as possible (transl. by S. Paul). 
However, as already noted above, there is a very thought-provoking exception to this rule. This involved the participation of metics in the festival of Artemis Kindyas, held in the Carian city of Bargylia. Following the hardships experienced in the wake of the revolt of Aristonicus at the end of the second century BCE, Bargylia reorganised the festivals held in honour of its goddess Artemis Kindyas, who was merited with having saved the city. Such was its gratitude towards the goddess - who had even appeared during the crisis - that the city wished to bestow even greater honours on her. To this end, it meticulously regulated the sacrifices that should be offered to the deity. Among other things, it was decided that the city should set aside a sum to pay for the bulls that the metics, i.e. the foreigners residing in the city, could offer in sacrifice to her and consume. But what is of real interest here is the reason that was given to justify this exceptional measure: "it has been decided that for the sacrifice to Artemis it is necessary to add 100 drachmas to the monies of the goddess for the metics, in order that the sacrifice [should be performed by them] and because it will be more magnificent if the metics also offer sacrifices". ${ }^{34}$ Namely, to make the event as memorable as possible, the city of Bargylia was willing to include non-citizens with an eye to swelling the numbers of those offering sacrificial victims to the goddess and was even willing to pay for the victims out of public funds.

Oenoanda did not go to that extreme. As has been seen, the villagers' bulls were probably paid for out of their own pockets. Nor were the reasons for involving non-citizens revealed, as was indeed the case in Bargylia. Naturally, both texts also differ in other aspects: while in Bargylia the text per se and the topos of aggrandisement ("[the sacrifice] will be more magnificent") formed part of the honours that the city wished to bestow on Artemis Kindyas, ${ }^{35}$ the purpose of the text of Oenoanda was to praise the euergetes and the cult's regulation. But the determined efforts of both cities to consolidate their position in the area was supposed to culminate in the most lavish festival possible, according to the canons of the period. Accordingly, it was necessary to employ all the resources available, i.e. the participation of the villages and also that of the neighbouring cities. ${ }^{36}$

To conclude briefly, the case of Oenoanda illustrates a situation that must have been fairly commonplace at the time: the imperial cult offered new opportunities for an encounter between the countryside and the city which

34 SEG 45.1508 B, ll. 5-6; see also LSCG 92.40, IV a.C. (Eretria).

35 For the use of superlative vocabulary in Hellenistic inscriptions, see Chaniotis 2013, op. cit. (n. 13).

36 In a subordinated position, for "syntax is semantics too", Östenberg 2009, op. cit. (n. 13), 11. 
benefitted both. Emperor worship provided a new framework of coexistence between the town and its territory. More than a form of integration or imposition, the participation of the villages seems to have been a result of the new possibilities that the imperial cult offered the city, its rulers, and its territory. In this example, the impact of Rome did not change the countryside physically, but it definitely generated a new landscape. 